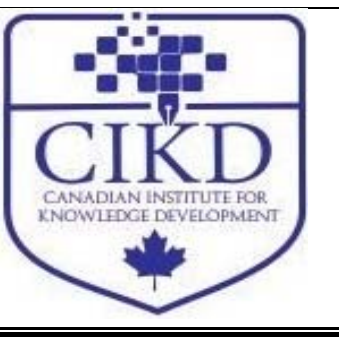

\title{
Ethical Climate as a Mediator between Employees' Organizational Silence Behaviors and their Trust in Leader: An Empirical Research on Insurance Sector Employees
}

\author{
Melisa E. Karabay ${ }^{1}$, İrge Şener ${ }^{2}$, Seher A. Tezergil ${ }^{3 *}$ \\ ${ }^{1}$ Associate Professor, School of Banking and Insurance, Marmara University, Turkey \\ ${ }^{2}$ Associate Professor, Faculty of Business Administration, Çankaya University, Turkey \\ ${ }^{3}$ Assistant Professor, School of Banking and Insurance, Marmara University, Turkey
}

\begin{abstract}
Keywords:

trust in leader,

organizational silence, ethical climate, insurance sector

Received

02 February 2017

Received in revised form 10 May 2018

Accepted

19 May 2018

Correspondence:

stezergil@marmara.edu.tr

Leaders play a major role in determining effectiveness across all organizational levels compromising (individual, team and units through their ability of ensuring trust among their subordinates and co-workers). In this study, the effect of trust in leader on employees' organizational silence behavior and ethical climate as a mediating role was investigated. In order to measure the impact of the perceptions of employees' trust in their leaders on their silence behavior particularly on defensive, acquiescent, and pro-social silence, a survey was conducted among 811 employees working in various insurance companies in Istanbul, Turkey. To test the hypotheses, hierarchical regression technique was used. According to the findings, trust in leader negatively affected silence intentions of employees. Furthermore, the findings presented a supporting evidence of the full mediating effect of ethical climate for the relation between trust in leader and overall organizational silence, and acquiescent and pro-social silence behavior. However, findings revealed that ethical climate had a partial mediating effect on the relation between trust in leader and defensive silence behavior of employees.
\end{abstract}


Establishing an ethical climate within an organization is important for enhancing positive employee behavior and eliminating negative behaviors. Ethical climate is an important dimension of organizational climate that is shaped by an extensive number of environmental factors (Denison, 1996) and it is considered a mirror of organization's value system including employees' values, policies and activities. Scholars have begun to address the issue of ethics related to various behaviors that affect the climate within the organization. Recently, corporations are much more engaged with corporate ethics like establishing ethical codes and organizing ethics committees for ensuring ethical compliance within the organization. However, this ethical behavior requires the policy of building a moral climate (Bowie \& Schneider, 2011). The relationship between ethical climate and employee behavior is critical because unethical behavior has proven to be extremely costly to organizations and society (Barsky, 2008). Past experience shows that misconduct can promote negative attitudes for the employees. According to Martin and Cullen's (2006) meta-analysis research, ethical climate forms an important antecedent of dysfunctional employee behavior. One of the dysfunctional employee behaviors at workplace is silence, which can lead to negative outcomes. On the other hand, organizational leaders have an important role for the development of ethical climate within an organization that is mainly related to trust of the employees to their leader. One of the fundamental concepts for effective leadership is trust as many studies have documented that trust promotes positive work outcomes when employees have positive perceptions of trust about their leaders. This is mostly based on the assumption that high trust in leader may induce beliefs among employees that the leader has powerful skills for establishing a favorable work environment inhibiting employee silence (Gao, Janssen, \& Shi, 2011).

In particular, it is important to understand the relations between these concepts. The relation between trust to the leader, organizational silence and ethical climate has not been thoroughly explored in management literature and this study can provide some useful insights. In particular, there is limited research that examined the mediating role of ethical climate on the relationship between trust in leader and employees' silence behavior. Within this frame, the purpose of this study is to investigate the effect of trust in leader on employees' silence behavior and to test the mediating effect of ethical climate on this relationship. This study is organized as follows: after introductory section the following section involves the conceptual framework of organizational silence, ethical climate and trust in leader and the relationship between the constructs in the literature. The study proceeds with the research methodology presenting empirical findings, conclusion and further recommendations.

\section{Conceptual Framework and Development of Hypotheses Organizational Silence}

Management can create an environment that supports organizational silence by the impact of environmental factors. These factors often promote negative workplace behaviors (Morrison $\&$ Milliken, 2000). Such silence behavior appears as the individuals inactively reacting to situations that they encounter in their organizations (Vakola \& Bouradas, 2005). Organizational silence and employees' silence behavior has often been subject to research interest in the literature. Despite employee silence was first mentioned in the literature by social scientist, 
Albert Hirchmann in 1970 (Tulubas \& Celep, 2012, p.1223), organizational silence became a popular topic starting from the early 2000s. The studies of Morrison and Milliken (2000), Milliken, Morrison, and Hewlin (2003), Dyne, Ang, \& Botero (2003), and Pinder and Harlos (2001) have given direction to literature related to organizational silence. Individuals in organizations face a choice about whether to speak up or remain silent about concerns that they have at work. This appears within the context of an organizational hierarchy, mostly fostered by the fear of managers punishing employees for speaking up (Morrison \& Milliken, 2003). Therefore, many employees choose not to voice their opinions and concerns about matters in their organizations because of fear of being characterized as 'troublemaker' (Huang, Vliert, \& Vegt, 2005; Vakola \& Bouradas, 2005).

Silence can be observed at two different levels as individual and organizational. At individual level, silence can be defined as the intentional withholding information by employees from others; which is referred to as employee silence (Johannesen, 1974, p. 29). When most employees of the organization choose to keep silent about organizational matters, silence becomes a collective behavior; which is referred to as organizational silence (Morrison \& Milliken, 2000, p. 706).

Organizational silence can occur at different types (Dyne et al., 2003; Pinder \& Harlos, 2001). According to Pinder and Harlos (2001), organizational silence can be differentiated as two basic forms: acquiescent silence which is passive withholding of relevant ideas, based on submission and resignation; and quiescent (defensive) silence which refers to more active withholding of relevant ideas in order to selfguard on consequences of speaking up which might be personally unpleasant. Dyne et al. (2003) added one more different type of organizational silence to the classification of Pinder and Harlos (2001) which is pro-social silence referring to withholding of work related information for the benefit of others. In sum, organizational silence can be classified as three different forms namely acquiescent silence, defensive silence and pro-social silence.

The relation of silence behavior with various organizational factors have been investigated by various researches. Some of these factors consist of motivation (Sözen, Yeloğlu, Fikret, 2009), organizational citizenship behavior (Kılıçlar \& Harbalioğlu, 2014), mobbing (Gül \& Özcan, 2011; Kaygın \& Atay, 2014), locus of control (Bakoğlu, Aşkun, \& Berber, 2009), organizational commitment (Eroğlu, Adıgüzel, \& Öztürk, 2011; Tangirala \& Ramanujam, 2008; Vakola \& Bouradas, 2005), cynicism (Karacaoğlu \& Küçükköylü, 2015), whistleblowing (Park \& Keil, 2009) and personality traits (Çetin, Karabay, Özcan, \& Taşkıran 2016).

\section{Trust in Leader}

Trust, has been conceptualized and studied across numerous disciplines; as "a psychological state comprising the intention to accept vulnerability based upon positive expectations of the intentions or behavior of another" (Rousseau, Sitkin, Burt, \& Camerer, 1998, p. 395). The importance of trust in leadership has also been emphasized in the other literatures across multiple disciplines (Dirks \& Ferrin, 2002). According to Yukl (1989, p. 272), "followers feel trust and respect toward the leader and they are motivated to do more than they are expected to do". Although it is defined in various ways in the literature, the definition of trust as "willingness of a party to be vulnerable to the actions of another party" by Mayer, Davis, \& 
Schoorman $(1995$, p. 712$)$ is the most widely used definition. In accordance to this definition, trust in leader can be viewed as employees' being vulnerable to their leaders. Trust in the leader is determined to a great extent by various aspects of the behavior of leader (Joseph \& Winston, 2005). When employees are treated fairly by a leader they trust, they are likely to think about their relationship with the leader in terms of social exchange rather than economic exchange (Walumbwa \& Schaubroeck, 2009). Therefore, trust is determined as instrumental in promoting group concerns based on social exchange (Wat \& Shaffer, 2005). According to social exchange theory, the relationship-based perspective implies that followers will reciprocate toward the other party in the relationship. Likewise, trust in primary leader should be associated with reciprocation primarily aimed at that referent (Dirks \& Ferrin, 2002, p. 615).

\section{Ethical Climate}

Organizational climate, which is mainly organizations' internal atmosphere (Koys \& DeCotiis, 1991), is an important research stream since it affects employees' motivation and attitudes which influences organizational performance (Stringer, 2002). Within an organization there exist many types of climate, as ethical climate being one of them that is an important component of organizational climate (Victor \& Cullen, 1988).

First introduced by Victor and Cullen (1988, p. 51), ethical climate is defined as the shared perceptions of organizational members, for norms, values and practices regarding appropriate organizational behavior. The considered correct organizational behavior and how the employees deal with ethical issues within the organization are the main topics of ethical climate (Cullen et al., 1993). Although, ethical climate refers to dominantly perceived ethically correct behaviors, it is also related to deviations from the expected behaviors. Since the experience of organizational members will be affected, ethical climate resembles to the value system of the organization (Cullen, Victor, \& Bronson, 2003). According to Victor and Cullen (1988), there exist three broad categories that include social norms, organizational forms or structures and firm-specific factors, which determine the perceived ethical climates of the organization.

Although, Victor and Cullen (1988) specified five ethical climate types, as instrumental, caring, rules, law and code and independence; in other studies alternative types of ethical climate has been suggested (e.g., in their study, Cullen et al. (2003) identified seven climates). In their meta-analytic research, Martin and Cullen (2006) determined three antecedents of ethical climate as external organization context, organizational form and strategic, and managerial orientations; which lead to formation of ethical climates. On the other hand, since it is associated with organizational performance (Wimbush \& Shepard, 1994), presence of an ethical climate is important for organizational outcomes. Ethical climate within the organization result in both positive as well as negative employee behaviors. The consequences of ethical climate are classified into four dysfunctional behavior which is a negative outcome and three positive outcomes which are job satisfaction, organizational commitment and psychological well-being (Martin \& Cullen, 2006).

\section{Trust, Organizational Silence and Ethical Climate}


Trust in supervision can affect various aspects of an employees' work behavior due to the power that the supervisor holds over employee attitudes (Mulki, Jaramillo, \& Locander, 2006). When there is a climate of trust, even under unfavorable conditions, such as those in the aftermath of a merger, it is likely that employees might take the initiative to speak up and raise concerns to top management and their supervisors since they will probably consider the context as favorable (Nikolaou et al., 2011). This is also valid for a trustworthy leader in organization.

When the supervisor is perceived as trustworthy and is able to create a trusting organizational climate, the unique relationship between two parties is established and cannot be copied; employees feel safer and productive and respond with loyalty to the organization (Davis, Schoorman, Mayer, R. C., \& Tan, 2000). Mulki et al. (2006) revealed that trust in supervisor mediates the effect of ethical climate on turnover intention. Although previous literature highlights the importance of trust in leader, there is limited evidence for trust in leader predicting silence behavior. Binikos (2008), Gül and Özcan (2011), Fard and Karimi (2015) have recently investigated the interaction between employee silence and trust. Nikolau et al. (2011), likewise, explored the role of organizational silence and trust on employees' attitudes in a post-merger stage. Tulubaş and Celep (2012) examined the effects of justice on faculty members' silence. They also tested whether trust in supervisor mediates the effect of perceived justice on faculty members' silence. Findings indicated that, trust in supervisor mediated the effect of perceived justice and perceived procedural justice on faculty members' silence.

In line with this previous literature, for this study the below hypotheses are proposed:

\section{$\mathbf{H}_{1}$ : Trust in leader has a negative effect on employees' silence behaviour. \\ $\mathbf{H}_{1 \mathbf{a}}$ : Trust in leader has a negative effect on employees' acquiescent silence behavior \\ $\mathbf{H}_{1 \mathbf{b}}$ : Trust in leader has a negative effect on employees' defensive silence behavior. \\ $\mathbf{H}_{1 \mathbf{c}}$ : Trust in leader has a negative effect on employees' pro-social silence behavior.}

Extant research has examined the consequences of ethical climate on specific job outcomes and often showed strong evidence that ethical climate is related to various job attitudes in organizations (Mulki et al., 2006; Okpara \& Wynn, 2008; Tsai \& Huang, 2008).

Despite addressing ethical climate with various job outcomes, yet limited research states that improving the ethical climate may be essential for improving employees' silence behavior (Wang \& Hsieh, 2013). We support the argument that if leaders maintain ethical norms and processes in organization then they can easily create a kind of particular ethical climate (Kaptein, Huberts, Avelino, \& Lasthuizen, 2005) that promotes less silence behavior. Employees in organizations can take correcting or eliminating action against prescribed or witnessed unethical or illegal issues only if they feel responsible (Miceli \& Near, 2005a, 2005b). Gökçe and Alataş (2015) investigated teachers' attitudes towards undesired behaviors at school. According to their findings, teachers mostly stated that they would prefer to whistle-blow internally and formally by identifying themselves. Schwepker, Ferrell, \& Ingram (1997) found that when organizations have a positive ethical climate, there appear less conflict between employees and managers. 
Most of the employees may choose to remain silent against the unethical behavior of colleagues or managers in their own workplaces. This can be related to many factors like fear of losing his job, lack of opportunity to express their ideas to their managers or lack of organizational culture (Elçi, Erdilek, Alpkan, \& Şener, 2014). Since ethical climate relates to the existence of organizational guidelines that dictate employee behaviors, it can enhance an employee's confidence that his or her supervisor can be trusted and behave ethically (Mulki et al., 2006). In this study, we contend that ethical climate will mediate the effects of trust in leader on silence behavior and therefore the following hypotheses of this study are developed as:

$\mathbf{H}_{2}$ : Ethical climate mediates the relationship between trust in leader and of employees' organizational silence behavior.

$\mathbf{H}_{\mathbf{2}}$ : Ethical climate mediates the relationship between trust in leader and of employees' acquiescent silence behavior.

$\mathbf{H}_{\mathbf{2 b}}$ : Ethical climate mediates the relationship between trust in leader and of employees' defensive silence behavior.

$\mathbf{H}_{2 \mathbf{c}}$ : Ethical climate mediates the relationship between trust in leader and of employees' pro-social silence behavior.

\section{Methodology}

\section{Sample and Data Collection}

This study focuses on the employees of the insurance sector. According to the "Turkish Insurance Market Outlook 2016-17" Report published by JLT Insurance and Reinsurance Company (2016), strong growth and profitability was witnessed in the Turkish insurance market over the last five years. The growing insurance sector in Turkey significantly increased the need for effective leadership, since more people will be employed in this sector.

A survey using questionnaires was conducted to collect field data from the financial insurance sector employees. There are 61 actively operating insurance companies in Turkey, of which 37 of them are non-life insurers, 19 of them are life and pension insurers, four of them are life insurers and one of them reinsurer (JLT Report, 2016). According to the statistics of 'Insurance Association of Turkey', 13.555 people work for insurance companies as of 31 December 2016. With a 5\% acceptable error rate and 1\% confidence level, the sample size is calculated as 633 . The questionnaires were distributed to 1.000 people and after the omission of incomplete surveys, there remained 811 useable surveys which forms the sample size of this study. The sample consists of people employed in insurance companies, insurance agents, and other insurance intermediaries in İstanbul, Turkey.

\section{Measures}

The constructs of this study are developed by using measurement scales adopted from prior studies. All constructs are measured using five-point Likert scales ranging from strongly disagree $(=1)$ to strongly agree $(=5)$. Items for measuring 'ethical climate' ( 7 items) were adopted from Schwepker (2001). The second part of the questionnaire, consists of the organizational silence scale developed by Dyne, Ang and Botero (2003). This scale consists of fifteen-items aiming to assess three sub-dimensions of organizational silence: acquiescent 
silence (five items), defensive silence (five items) and pro-social silence (five items). In the third part of the questionnaire, items for trust in leader were adopted from the scale of Rich (1997). The last part of the questionnaire consists of close-ended questions developed to determine the demographical characteristics of the participants.

\section{Data Analysis and Empirical Findings}

Data were analyzed using SPSS program. The demographical characteristics of respondents were analyzed by frequency analysis. Furthermore; factor analysis were completed for the factor loadings of the scales, pearson correlation technique and hierarchical regression of Baron \& Kenny were conducted in order to test the hypotheses. Furthermore, in order to confirm the mediation effect, Sobel-test calculation was conducted between the regression values.

\section{Descriptive Statistics}

According to the demographic information, $53.8 \%$ of the participants were male and $46.2 \%$ of the participants were female; $64.3 \%$ of the participants were single. It was found that most of the participants were young where $17.5 \%$ of the participants were aged between $18-25,65.7 \%$ of the participants were aged between $26-35,15.4 \%$ of the participants were aged between $36-$ 45 , and only $1.4 \%$ of the participants were aged 46 or above. In terms of education of the participants, $4.2 \%$ of the participants were high school graduates, $34.2 \%$ of the participants had a bachelor's degree, $52.4 \%$ of the participants held a master's degree, $9.2 \%$ of the participants had a PhD degree. Additionally, $18.9 \%$ of the participants had a work experience of less than 1 year, $24.3 \%$ of the participants had a work experience of $1-5$ years, $30 \%$ of the participants have had a work experience of 6-10 years, $26.6 \%$ of the participants had been working in the sector for more than 11 years.

\section{Factor Analysis}

The construct validity of items was tested by factor analysis, with a principal component analysis through varimax rotation. All factors passed the KMO Measure of Sampling Adequacy (.89) and Barlett Test of Sphericity $(16.14 ; p=.000)$ which means that the data set is appropriate for factor analyses. The factor loadings are shown in Table 1.

Table 1

Factor Analysis

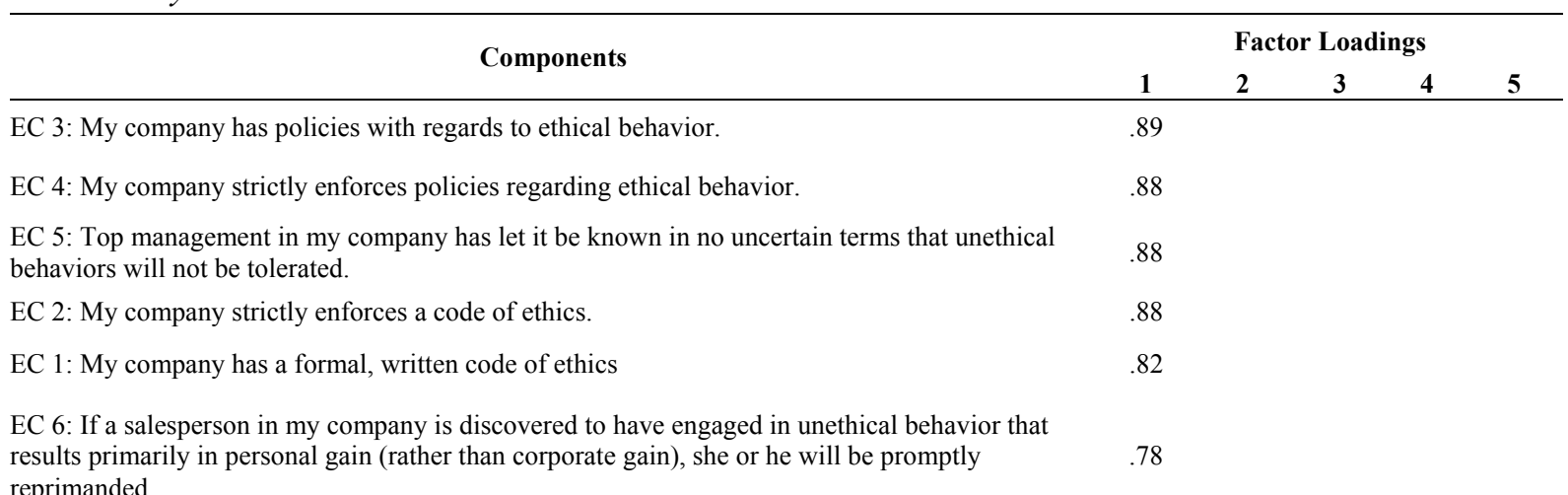


EC 7: If a salesperson in my company is discovered to have engaged in unethical behavior that results in primarily corporate gain (rather than personal gain), she or he will be promptly reprimanded.

TIL 2: Feeling a strong loyalty to my manager.

$\begin{array}{lr}\text { TIL 5: Having a strong sense of loyalty toward my manager. } & .89\end{array}$

$\begin{array}{ll}\text { TIL 3: Having complete faith in the integrity of my manager. } & .88\end{array}$

TIL 4: Feeling quite confident that my manager will always try to treat me fairly. $\quad .87$

TIL 1: My manager would never try to gain an advantage by deceiving workers.

DS 3: Omitting pertinent facts in order to protect him//herself.

DS 4: Avoiding expressing ideas for improvements, due to self-protection.

DS 5: Withholding his/her solutions to problems because he/she is motivated by fear.

DS 1: Does not speaking up and suggesting ideas for change, based on fear.

DS 2: Withholding relevant information due to fear.

PSS 3: Withstanding pressure from others to tell organizational secrets.

PSS 5: Protecting confidential organizational information appropriately, based on concern for the organization.

PSS 2: Protecting proprietary information in order to benefit the organization.

PSS 4: Refusing to divulge information that might harm the organization.

PSS 1: Withholding confidential information, based on cooperation.

AS 1: Unwilling to speak up with suggestions for change because he/she is disengaged.

AS 5: Withholding ideas about how to improve the work around here, based on being disengaged.

AS 2: Passively withholding ideas, based on resignation.

AS 4: Keeping any ideas for improvement to him/ herself because he/she has low self-efficacy to make a difference.

Cronbach Alpha (a)

71.64

Extraction Method: Principal Component Analysis. Rotation Method: Varimax with Kaiser Normalization. $E C$ : Ethical Climate; AS: Acquiescent Silence; DS: Defensive Silence; PSS: Pro- Social Silence; TIL: Trust in Leader.

Based on the factor loadings, theoretical model of the research is demonstrated in Figure 1.

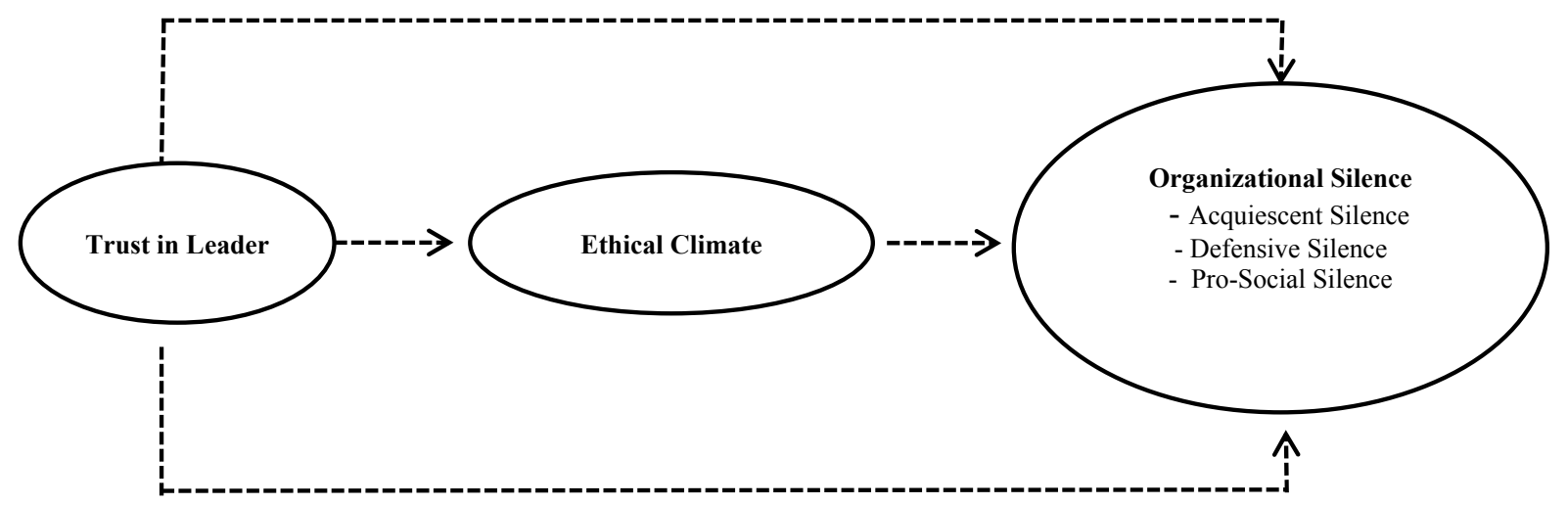

Figure 1. Research model

\section{Correlation Analysis}


In order to test the effect of trust in leader on organizational silence behavior and whether ethical climate plays a mediator role in this relation, correlation analysis was conducted to analyze the relations between all of the variables .

Table 2

Descriptive Statistics and Correlation Results

\begin{tabular}{|c|c|c|c|c|c|c|c|c|c|}
\hline & Variables & $\mathbf{M}$ & SD & 1 & 2 & 3 & 4 & 5 & 6 \\
\hline 1 & Acquiescent silence & 1.90 & .76 & 1 & & & & & \\
\hline 2 & Defensive Silence & 1.68 & .77 & $.60^{* *}$ & 1 & & & & \\
\hline 3 & Prosocial Silence & 4.26 & .80 & $-.21^{* *}$ & $-.16^{* *}$ & 1 & & & \\
\hline 4 & Trust in Leader & 4.08 & .89 & $-.31^{* *}$ & $-.30^{* *}$ & $.16^{* *}$ & 1 & & \\
\hline 5 & Ethical Climate & 3.79 & .99 & $-.16^{* *}$ & $-.22^{* *}$ & .06 & $.46^{* *}$ & 1 & \\
\hline 6 & Overall Organizational Silence & 2.67 & .47 & $.68^{* *}$ & $.75^{* *}$ & $.40^{* *}$ & $-.22^{* *}$ & $-.16^{* *}$ & 1 \\
\hline
\end{tabular}

Sample Size $=811 * \mathrm{p}<.05, * * \mathrm{p}<.01$

The means and standard deviations of each variable and correlation matrix of all variables were calculated, as shown in Table 2. The correlation coefficients were calculated and it was found that each variable was significantly correlated to the others for all the participants. As indicated in Table 2, organizational silence is negatively correlated with trust in leader $(\mathrm{r}=$ $.22)$ and ethical climate $(r=-.16)$.

\section{The Results of the Regression Analysis}

In this research, we examined whether ethical climate mediated the relationship between trust in leader and organizational silence by hierarchical regression models. Specifically we conducted a set of multiple regression analyses to determine whether the conditions of mediation outlined by Baron and Kenny (1986) were met: (1) if independent variable is related to dependent variable, (2) whether independent variable is related to mediating variable, (3) whether mediating variable is related to dependent variable, (4) if the association between independent and dependent variable is attenuated when mediating variable is included. In these circumstances; mediation should be evident when 1) paths $C, A$ and $B$ are significant and 2) $\beta$ for trust in leader in path $C$ is either insignificant (in case of full mediation) or substantially less significant than in path $C$ (in case of partial mediation) (Baron \& Kenny, 1986; Preacher \& Hayes, 2008).

Table 3

Regression Results of Mediation Effect of Ethical Climate between Trust and Acquiescent Silence Interaction

\begin{tabular}{lllcccc}
\hline Model 1 & Independent Variables & Dependent Variables & $\boldsymbol{\beta}$ & $\boldsymbol{p}$ & adj. $\boldsymbol{R}^{\mathbf{2}}$ & $\boldsymbol{F}$ \\
\hline \multirow{2}{*}{ 1. Regression } & Trust in Leader & Acquiescent silence & -.16 & .001 & .02 & 21.99 \\
2. Regression & Trust in Leader & Ethical Climate & .46 & .001 & .21 & 22.95 \\
3. Regression & Ethical Climate & Acquiescent silence & -.31 & .001 & .10 & 91.11 \\
& Trust in Leader & Acquiescent silence & -.01 & .63 & .10 & 45.57 \\
4. Regression & Ethical Climate & & -.31 & .001 & & \\
\end{tabular}

As illustrated in Table 3, trust in leader $\left(p<.001 ; \beta=-.16 ; R^{2}=.02\right)$ had a significant negative effect on acquiescent silence. Therefore, $\mathrm{H}_{1}$ a hypothesis was accepted. When ethical 
climate is included as a mediating variable to the first regression model, the relationship between the trust in leader and acquiescent silence disappeared $\left(p=.630 ; \beta=-.01 ; R^{2}=.10\right)$ whereas the effect of ethical climate on acquiescent silence still remained significant. This finding demonstrated that ethical climate had a full mediation effect between trust in leader and acquiescent silence relation. Accordingly, the hypothesis of $\mathrm{H}_{2 \mathrm{a}}$ is was accepted.

Table 4

Regression Results of Mediation Effect of Ethical Climate between Trust and Defensive Silence Interaction

\begin{tabular}{lllcccc}
\hline Model 2 & Independent Variables & Dependent Variables & $\boldsymbol{\beta}$ & $\boldsymbol{p}$ & adj. $\boldsymbol{R}^{\mathbf{2}}$ & $\boldsymbol{F}$ \\
\hline 1. Regression & Trust in Leader & Defensive Silence & -.24 & .001 & .05 & 50.78 \\
2. Regression & Trust in Leader & Ethical Climate & .46 & .001 & .21 & 224.95 \\
3. Regression & Ethical Climate & Defensive Silence & -.33 & .001 & .11 & 102.62 \\
& Trust in Leader & Defensive Silence & -.11 & .003 & .12 & 56.12 \\
\hline
\end{tabular}

In the second regression model, the results indicated that trust in leader also negatively affected defensive silence $\left(p=.001 ; \beta=-.24 ; R^{2}=.05\right)$. Thus, $\mathrm{H}_{1 \mathrm{~b}}$ hypothesis was accepted. When ethical climate is included as a mediating variable to regression model, the relationship between the trust in leader and defensive silence diminished $\left(p=.003 ; \beta=-.11 ; R^{2}=.12\right)$ whereas the effect of ethical climate on defensive silence remained significant. This finding demonstrated that ethical climate had a partial mediation effect between trust in leader and defensive silence relation. Therefore, the hypothesis $\mathrm{H}_{2 b}$ was accepted.

Table 5

Regression Results of Mediation Effect of Ethical Climate between Trust and Pro-Social Silence Interaction

\begin{tabular}{|c|c|c|c|c|c|c|}
\hline Model 3 & Independent Variables & Dependent Variables & $\boldsymbol{\beta}$ & $p$ & $\operatorname{adj} . R^{2}$ & $\boldsymbol{F}$ \\
\hline 1. Regression & Trust in Leader & Pro-social silence & -.06 & .07 & .003 & 3.30 \\
\hline 2. Regression & Trust in Leader & Ethical Climate & .46 & .001 & .21 & 22.95 \\
\hline 3. Regression & Ethical Climate & Pro-social silence & -.16 & .001 & .02 & 21.61 \\
\hline \multirow{2}{*}{ 4. Regression } & Trust in Leader & \multirow{2}{*}{ Pro-social silence } & -.01 & .717 & \multirow[t]{2}{*}{.02} & \multirow{2}{*}{10.83} \\
\hline & Ethical Climate & & .16 & .001 & & \\
\hline
\end{tabular}

In Table 5, the third regression analysis revealed the negative effect of trust in leader on pro-social silence $\left(p=.007 ; \beta=-.06 ; R^{2}=.003 ; F=3.30\right)$. Therefore, $\mathrm{H}_{1 \mathrm{c}}$ hypothesis was accepted. When ethical climate was included in this relation as a mediating variable, the relationship between the trust in leader and pro-social silence disappeared ( $\mathrm{p}=.717 ; \beta=-.01$; $R^{2}=.02 ; F=10.83$ ) whereas the effect of ethical climate on pro-social silence remained significant. This finding indicated that ethical climate had a full mediation effect between trust in leader and pro-social silence relation. According to this result, hypothesis of $\mathrm{H}_{2 \mathrm{c}}$ was also accepted.

Table 6

Regression Results of Mediation Effect of Ethical Climate on Trust and Overall Organizational Silence Interaction

\begin{tabular}{lllllr}
\hline Model 4 & $\begin{array}{l}\text { Independent } \\
\text { Variables }\end{array}$ & Dependent Variables & $\boldsymbol{\beta}$ & $\boldsymbol{p}$ & adj. $\boldsymbol{R}^{\mathbf{2}}$ \\
\hline 1. Regression & Trust & Organizational silence & -.16 & .001 & .02
\end{tabular}




\begin{tabular}{lllllll} 
2. Regression & Trust & Ethical Climate & .46 & .001 & .21 & 224.95 \\
3. Regression & Ethical Climate & Organizational silence & -.22 & .001 & .05 & 43.19 \\
4. Regression & Trust & Organizational silence & -.07 & .04 & .05 & 23.58 \\
& Ethical Climate & & -.19 & .001 & & \\
\hline
\end{tabular}

As presented in Table 6 , the fourth regression analysis revealed the negative effect of trust in leader on overall silence behavior $\left(p=.001, \beta=-.16 ; R^{2}=.02 ; F=22.45\right)$. According to this result, $\mathrm{H}_{1}$ hypothesis was accepted. When ethical climate was included in the relation as a mediating variable, the relationship between the trust in leader and organizational silence disappeared $\left(p=.04 ; \beta=-, 07 ; \mathrm{R}^{2}=.005 ; F=23.58\right)$ whereas the effect of ethical climate on organizational silence remained significant. This finding shows that ethical climate had a full mediation effect between trust in leader and overall organizational silence relation. Therefore, hypothesis $\mathrm{H}_{2}$ was accepted.

Mediation effect forms a problem when it appears in case each of the two variables is related significantly as well as a third variable take places as a mediator (Türkay, Ünal, \& Taşar, 2011). Researchers often use Sobel Test (Sobel, 1982) to ensure the mediating effect in addition to the main hypothesis testing. Sobel Test allows researchers to substantiate findings of full mediation (Jackson, Mun, \& Park, 2013). The Sobel Test statistics conducted in this research aimed to examine whether ethical climate had a mediating effect between trust in leader and organizational silence.

Table 7

Sobel Test Calculations

\begin{tabular}{lcc}
\hline Model & Sobel-Test Statistic & $\begin{array}{c}p \\
\text { (two-tailed) }\end{array}$ \\
\hline Trust in Leader - Ethical Climate- Organizational Silence & $\mathbf{- 2 . 9 0}$ & $\mathbf{. 0 0 3}$ \\
\hline
\end{tabular}

As illustrated in Table 7, the test statistics confirmed the mediation effect of ethical climate. Therefore, $\mathrm{H}_{2}$ (Ethical climate mediates the relationship between trust in leader and employees' organizational silence behavior) hypothesis was supported.

\section{Discussion and Conclusion}

Today, organizations need employees reacting to misconduct, responding to the challenges, having confidence to share information and knowledge as well as having ability to stand up for their own beliefs. Although the phenomenon of organizational silence is widely seen in organizations, there is few empirical evidence regarding its nature and main predictors. Many scholars have addressed that silence climate has an impact on organization's ability to detect errors and learn and therefore, organizational effectiveness is negatively affected. Nevertheless, the existing literature needs further research in organizational behavior that can reveal abstract consequences with regard to the relationship between ethical climate and silence behavior of employees.

There is a growing body of literature that demonstrates the importance of trust in the leader on positive job outcomes. Trust is vital in organizations since it connects the follower to the leader through the organizational goals. Merely enacting traditional leadership behaviors does not guarantee followers' satisfaction and motivation on their performance. Followers need to trust the leader in order to feel positively about the leader and to exert positive attitudes. 
Building trust is critical, however, organizations need to develop policies or structures that encourage employees to regulate their own behavior, enforce standards and be accountable for the wrongdoing of others. This can be promoted by establishing an ethical climate in organizations. Ethical climate is today much more influential on performing organizational goals. The social environment or ethical climate in this case, provides information to individuals as to the appropriateness of behavior they see in the work environment. This confirms the fact that ethical climate is linked to various behaviors in organizations. Thus, a management philosophy that focuses on developing a moral climate within the organization can help develop moral people and moral managers establishing a desired working climate.

In this study, the effect of ethical climate on organizational silence behavior was investigated. In addition, the research also tested whether ethical climate plays a mediating role in this interaction. As the results revealed, trust in leader negatively affected silence behaviours of employees. Furthermore, the findings presented a supporting evidence of the full mediating effect of ethical climate between trust in leader and organizational silence behavior. This research has a number of intended contributions. Since there was a limited amount of theoretical work that have highlighted the link between ethical climate and silence behavior, this study presented an expanded evidence for the literature. Second, we sought to provide a theoretical rationale for linking ethical climate as a mediator on silence behavior through trust in leader. As the literature presents many assumptions that, more the employees work in an ethical climate, the less they will be likely to engage in misconduct.

Regardless of contributions, the study has some limitations. Research model indicated that an expanded model of silence behavior holds tru for insurance employees in Turkey. Only additional research can determine whether these results will be found in other samples and contexts. Furthermore, ethical misconduct is often affected by demographic factors of the employee traits promoting silence. These could be included in a further research to provide more clear evidence. Finally, because staffing was not directly measured, more research is needed to fully understand if types of ethical climate (egoistic, benevolent, etc.) are also stronger predictors of silence behavior.

\section{References}

Aşkun, B., \& Berber, A. (2009, September). Does locus of control lead to "silence" of academicians. Paper presented at the Second International Conference On Social Sciences, Social Sciences Research Society, Turkey.

Bakoğlu, R., Aşkun, B., \& Berber, A. (2009). Does locus of control lead to "silence" of academicians. Journal of Economics Finance and Accounting, 2, 17-36.

Baron, R. M., \& Kenny, D. A. (1986). Moderator-mediator variables distinction in social psychological research: Conceptual, strategic and statistical considerations, Journal of Personality and Social Psychology, 51(6), 1173-1182.

Barsky, A. (2008). Understanding the ethical cost of organizational goal-setting: A review and theory development. Journal of Business Ethics, 81(1), 63-81.

Binikos, E. (2008). Sounds of silence: organizational trust and decisions to blow the whistle. Journal of Industrial Psychology, $34(3), 48-59$.

Bowie, N. E., \& Schnieder, M. (2011). Business ethics for dummies. US: John Wiley \& Sons.

Çetin, C., Karabay, M. E., Özcan, E. D., \& Taşkıran, E. (2016). The effect of personality traits on organizational silence: A research on service industry. In L. Altınay \& S. Poudel (Eds.), Enhancing customer experience in the service industry: A global perspective (pp.130-145). UK: Cambridge Scholar Publishing.

Cullen, J. B., Parboteeah, K. P., \& Victor, B. (2003). The effects of ethical climates on organizational commitment: A twostudy analysis. Journal of Business Ethics, 46(2), 127-141. 
Cullen, J. B., Victor, B., \& Bronson, J. B. (1993). The ethical climate questionnaire: An assessment of its development and validity. Psychological Report, 73(2), 667-674.

Davis, J. H., Schoorman, F. D., Mayer, R. C., \& Tan, H. H. (2000). The trusted general manager and business unit performance: Empirical evidence of a competitive advantage. Strategic Management Journal, 21(5), 563-576.

Denison, D. (1996). What is the difference between organizational culture and organizational climate? A native's point of view on a decade of paradigm wars. The Academy of Management Review, 21(3), 619-654.

Dirks, K. T., \& Ferrin, D. L. (2002). Trust in leadership: meta-analytic findings and implications for research and practice. Journal of Applied Psychology, 87(4), 611-628.

Dyne, L. V., Ang, S., \& Botero, I. C. (2003). Conceptualizing employee silence and employee voice as multidimensional constructs. Journal of Management Studies, 40(6), 1359-1392.

Elçi, M., Erdilek, M. K., Alpkan, L., \& Şener, İ. (2014). The mediating role of mobbing on the relationship between organizational silence and turnover intention. Procedia-Social and Behavioral Sciences, 150, 455-464.

Eroğlu H., Adıgüzel, O., \& Öztürk U. (2011). Dilemma of silence vortex and commitment: relationship between employee silence and organizational commitment. The Journal of Faculty of Economics and Administrative Sciences, 16(2), 97-124.

Fard, P. G., \& Karimi, F. (2015). The relationship between organizational trust and organizational silence with job satisfaction and organizational commitment of the employees of university. International Education Studies, 8(11), $219-227$.

Gao, L., Janssen, O., \& Shi, K. (2011). Leader trust and employee voice: The moderating role of empowering leader behaviors. The Leadership Quarterly, 22(4), 787-798.

Gökçe, T. A., \& Alataş, H. (2015). Teachers' reactions towards undesirable behaviors of administrators: Whistleblowing or keeping silent? Journal of Computer and Education Research, 3(6), 99-116.

Gül, H., \& Özcan, N. (2011). The relationships between mobbing and organizational silence: An empirical study in the special provincial administration of karaman. Journal of Kahramanmaraş Sütçü Imam University Economics and Administrative Sciences, 2, 107-134.

Huang, X., Vliert, E. V. D., \& Vegt, G. V. D. (2005). Breaking the silence culture: stimulation of participation and employee opinion withholding cross-nationally. Management and Organization Review, 1(3), 459-482.

Jackson, J. D., Mun, Y. Y., \& Park, J. S. (2013). An empirical test of three mediation models for the relationship between personal innovativeness and user acceptance of technology. Information and Management, 50(4), 154-161.

Jardine Llyod Thompson (JLT) Group (2016). Turkish Insurance Market Outlook 2016-17. Johannesen, R. L. (1974). The functions of silence: a plea for communication research. Western Journal of Communication, 38(1), 25-35.

Joseph, E. E., \& Winston, B. E. (2005). A correlation of servant leadership, leader trust, and organizational trust. Leadership and Organization Development Journal, 26(1), 6-22.

Kaptein, M., Huberts, L., Avelino, S., \& Lasthuizen, K. (2005). Demonstrating ethical leadership by measuring ethics: A survey of us public servants. Public Integrity, 7(4), 299-311.

Karacaoğlu, K., \& Küçükköylü, C. (2015). The effect of employee silence on organizational cynicism: A study on public employees. Ege Academic Review, 15(3), 401-408.

Kaygın, E., \& Atay, M. (2014). The influence of mobbing on organizational trust and organizational silence. The Journal of Faculty of Economics and Administrative Sciences, 18(2), 95-113.

Kılıçlar, A., \& Harbalıŏlu, M. (2014). Relationship between organizational silence and organizational citizenship behavior: A case study on five stars hotels in antalya. Journal of Business Research-Türk, 6(1), 328-346.

Koys, D. J., \& DeCotiis, T. A. (1991). Inductive measures of psychological climate. Human Relations, 44(3), $265-285$.

Martin, K., \& Cullen, J. (2006). Continuities and extensions of ethical climate theory: a meta-analytic review. Journal of Business Ethics, 69(2), 175-194.

Mayer, R. C., Davis, J. H., \& Schoorman, F. D. (1995). An integrative model of organizational trust. Academy of Management Review, 20(3), 709-734.

Miceli, M. P., \& Near, J. P. (2005a). Standing up or standing by: What predicts blowing the whistle on organizational wrongdoing? Research in Personnel and Human Resources Management, 24, 95-136.

Miceli, M. P., \& Near, J. P. (2005b). Whistle-blowing and positive psychology. Positive Psychology in Business Ethics and Corporate Responsibility, 1, 85-102.

Milliken, F. J., Morrison, E. W., \& Hewlin, P. F. (2003). An exploratory study of employee silence: Issues that employees don't communicate upward and why. Journal of management studies, 40(6), 1453-1476. 
Morrison, E. W., \& Milliken, F. J. (2000). Organizational silence: A barrier to change and development in a pluralistic world. Academy of Management Review, 25(4), 706-725.

Morrison, E. W., \& Milliken, F. J. (2003). Speaking up, remaining silent: The dynamics of voice and silence in organizations. Journal of Management Studies, 40(6), 1353-1358.

Mulki, J. P., Jaramillo, F., \& Locander, W. B. (2006). Effects of ethical climate and supervisory trust on salesperson's job attitudes and intentions to quit. Journal of Personal Selling and Sales Management, 26(1), 19-26.

Nikolaou, I., Vakola, M., \& Bourantas, D. (2011). The role of silence on employees' attitudes "the day after" a merger. Personnel Review, 40(6), 723-741.

Okpara, J. O., \& Wynn, P. (2008). The impact of ethical climate on job satisfaction and commitment in nigeria: Implications for management development. Journal of Management Development, 27(9), 935-950.

Park, C., \& Keil, M. (2009). Organizational silence and whistle-blowing on it projects: An integrated model. Decision Sciences, 40(4), 901-918.

Pinder, C. C., \& Harlos, K. P. (2001). Employee silence: Quiescence and acquiescence as responses to perceived injustice. Research in Personnel and Human Resources Management, 20, 331-369.

Preacher, K. J., \& Hayes, A. F. (2008). Asymptotic and resampling strategies for assessing and comparing indirect effects in multiple mediator models. Behavior research methods, 40(3), 879-891.

Rich, G. A. (1997). The sales manager as a role model: Effects on trust, job satisfaction and performance of salespeople. Journal of the Academy of Marketing Science, 25(4), 319-328.

Rousseau, D. M., Sitkin, S. B., Burt, R. S., \& Camerer, C. (1998). Not so different after all: A cross-discipline view of trust. Academy of Management Review, 23(3), 393-404.

Schwepker, C. H. (2001). Ethical climate's relationship to job satisfaction, organizational commitment and turnover intention in the salesforce. Journal of Business Research, 54(1), 39-52.

Schwepker, C. H., Ferrell, O. C., \& Ingram, T. N. (1997). The influence of ethical climate and ethical conflict on role stress in the sales force. Journal of the Academy of Marketing Science, 25(2), 99-108.Sobel, M. E. (1982). Asymptotic confidence intervals for indirect effects in structural equation models. Sociological Methodology, 13, 290-312.

Sözen, C., Yeloğlu, H. O., \& Fikret, A. (2009). To keep silent against inequality: An empirical study on the motivation of blue-collar workers. The Journal of Faculty of Economics and Administrative Sciences, 22, 395-408.

Stringer, R. A. (2002). Leadership and organizational climate. Upper Saddle River, NJ: Prentice Hall.Tangirala, S., \& Ramanujam, R. (2008). Employee silence on critical work issues: The cross-level effects of procedural justice climate. Personnel Psychology, 61(1), 37-68.

Tsai, M. T., \& Huang, C. C. (2008). The relationship among ethical climate types, facets of job satisfaction and the three components of organizational commitment: A study of nurses in taiwan. Journal of Business Ethics, 80(3), 565-581.

Tulubaş, T., \& Celep, C. (2012). Effect of perceived procedural justice on faculty members' silence: the mediating role of trust in supervisor. Procedia-Social and Behavioral Sciences, 47, 1221-1231.

Türkay, O., Ünal, A., \& Taşar, O. (2011). The effects of emotional labor on job commitment under the determination of motivational and structural variables. Journal of Social Sciences, 7(14), 201-222.

Vakola, M., \& Bouradas, D. (2005). Antecedents and consequences of organizational silence: an empirical investigation. Employee Relations, 27(5), 441-458.

Victor, B., \& Cullen, J. B. (1988). The organizational bases of ethical work climates. Administrative Science Quarterly, 33(1), $101-125$.

Walumbwa, F. O., \& Schaubroeck, J. (2009). Leader personality traits and employee voice behavior: Mediating roles of ethical leadership and work group psychological safety. Journal of Applied Psychology, 94(5), 1275-1286.

Wang, Y. D., \& Hsieh, H. H. (2013). Organizational ethical climate, perceived organizational support and employee silence: A cross-level investigation. Human Relations, 66(6), 783-802.

Wat, D., \& Shaffer, M. A. (2005). Equity and relationship quality influences on organizational citizenship behaviors: The mediating role of trust in the supervisor and empowerment. Personnel Review, 34(4), 406-422.

Wimbush, J. C., \& Shepard, J. M. (1994). Toward an understanding of ethical climate: its relationship to ethical behavior and supervisory influence. Journal of Business Ethics, 73(8), 637-647.

Yukl, G. (1989). Managerial leadership: A review of theory and research. Journal of management, 15(2), 251-289. 